\title{
IMIONA CHRZESTNE MIESZKAŃCÓW ISKRZYNI W XIX WIEKU NA PODSTAWIE METRYK PARAFII KROŚCIENKO WYŻNE Z LAT 1848-1900
}

W badaniach demograficzno-historycznych księgi metrykalne są jednym z cenniejszych źródeł. Dotyczy to szczególnie okresu prestatystycznego ${ }^{2}$. To co wyróżnia rejestrację metrykalną od innych źródeł wykorzystywanych w badaniach nad stanem i ruchem naturalnym ludności, to przede wszystkim jej powszechność. W księgach metrykalnych zapisywano zarówno stany uprzywilejowane jak i chłopów, a rejestracja prowadzona była na terenie całego państwa ${ }^{3}$. Oprócz danych stricte demograficznych związanych z ruchem naturalnym, zawierają szereg dodatkowych informacji, które rzucają światło na historię społeczną oraz szeroko pojętą kulturę minionych epok. Jednym z często poruszanych tematów (w ostatnich latach) są kwestie nazewnictwa, szczególnie w kontekście odkrycia motywów, którymi kierowali się rodzice przy wyborze imienia chrzestnego dla swojego dziecka ${ }^{4}$. W literaturze przedmiotu wymienia się różne czynniki

* Piotr Rachwał - dr historii, adiunkt w Instytucie Historii, Wydział Humanistyczny KUL.

${ }^{1}$ Podstawę źródłową naszych badań stanowią metryki kościelne przechowywane w archiwum parafialnym w Krościenku Wyżnym (dalej AP) - Księga urodzeń (ochrzczonych) 1841-1889, 18901906. Księgi metrykalne były prowadzone oddzielnie dla każdej miejscowości, tj. Krościenka Wyżnego (siedziba parafii) oraz Iskrzyni. Stan zachowania metryk jest bardzo dobry. Zapisy sporządzano po łacinie, a formularz wpisu miał formę tabeli. Więcej na temat zasad rejestracji metrykalnej w zaborze austriackim zob.: B. Kumor, Przepisy państwowe i kościelne dotyczące metryk kościelnych w zaborze austriackim (1800-1914), PDP, 7(1975), s. 93-107.

${ }^{2}$ J. Z. Holzer, Powszechne spisy ludności. Świat-Europa-Polska, w: Spisy ludności Rzeczpospolitej Polskiej 1920-2002, Warszawa 2002, s. 30-53.

${ }^{3} \mathrm{O}$ możliwościach badawczych w oparciu o zapisy metrykalne oraz dotychczasowy dorobek w tym zakresie był omawiany wielokrotnie. Zobacz m. in.: K. Dobrowolski, Znaczenie metryk kościelnych dla badań naukowych, „Roczniki Towarzystwa Heraldycznego we Lwowie”, 5 (1920) s. 90-110; I. Gieysztorowa, Wstęp do demografii staropolskiej, Warszawa 1976; Z. Sułowski, Stulecie polskiej demografii historycznej (1882-1892), „Przeszłość Demograficzna Polski” (PDP), 15 (1984), s. 9-35; C. Kuklo, Polska demografia przeszłości u progu XXI wieku, PDP, 22 (2001) s. 7-32.

${ }^{4}$ Do pionierskich prac z tego zakresu należy artykuł Z. Sułowskiego, Imiona chrzestne $w$ pa- 
mogące mieć wpływ na ten wybór. Rodzima kultura Słowian przesycona magią i przesądem upatrywała $w$ imionach funkcji ochronnych, i odstraszających złe duchy ${ }^{5}$.Wraz z przyjęciem chrześcijaństwa rozpowszechnił się zwyczaj nadawania imion świętych chrześcijańskich, a imiennictwo słowiańskie powoli zanikało. Wyjątek stanowią imiona, które mają motywację świętych i błogosławionych ${ }^{6}$. $\mathrm{Z}$ motywacją tą łączy się zwyczaj nadawania imion występujących w kalendarzu w dniu urodzin lub chrztu dziecka ${ }^{7}$. Wśród innych czynników mających wpływ na wybór imienia, wymienia się także tradycję rodzinną, nadawanie dzieciom imion bohaterów świeckich, literackich czy w końcu zmieniającą się modę ${ }^{8}$. Analizując motywy wyboru imienia należy także pamiętać o czynnikach oddziałujących lokalnie na daną społeczność. W grę mogą wchodzić tu np. lokalne kulty świętych, wezwanie kościoła, a nawet struktura społeczno-zawodowa ludności.

Możliwości późniejszego porównania specyfiki lokalnej omawianego zjawiska pozwalają na formułowanie ogólniejszych wniosków na temat czynników wpływających na wybór konkretnego imienia. Celem naszych rozważań nad imionami mieszkańców Iskrzyni jest poszerzenie wiedzy z zakresu antroponimii wsi galicyjskiej w XIX w.

W XIX w. wieś Iskrzynia należała do Parafii Krościenko Wyżne (powiat Krosno). Zaludnienie w 1860 roku wynosiło 745 osób. Najliczniejszą grupę zawodową stanowili rolnicy -244 , następnie tkacze -9 oraz wojskowi $-8^{9}$. W księgach metrykalnych za lata 1848-1900 zanotowano 1522 chrzty, z czego 781 przypadło na chłopców. Najwięcej noworodków ochrzczono w styczniu, marcu, kwietniu i maju (ok. $40 \%$ wszystkich ochrzczonych dzieci).

Elementem sakramentu chrztu jest włączenie nowonarodzonego człowieka do wspólnoty chrześcijańskiej poprzez obrzęd obmycia wodą. Wraz z wprowadzeniem praktyki chrztu dzieci (od IV w.) rozpowszechnił się zwyczaj nadawania dziecku przy chrzcie imienia, od XV w. kilku, co od XVIII staje się powszechnym zwyczajem. Dla podkreślenia przynależności do wspólnoty zbawionych wybiera się imię świętego patrona ${ }^{10}$.

rafii Piotrawin w XVII-XIX w., „Roczniki Humanistyczne”, 20 (1972) z. 2, s. 99-116. Szersze omówienie problematyki badań onomastycznych prowadzonych przez historyków w tym zakresie zob. C. Kuklo, Demografia Rzeczpospolitej przedrozbiorowej, Warszawa 2009, s. 325-328.

${ }^{5}$ M. Malec, Imię w polskiej antroponimii i kulturze, Kraków 2001, s. 18, 116.

${ }^{6}$ H. Fros, F. Sowa, Księga imion, t. 6, Kraków 2007, s. 632-633.

${ }^{7}$ Dotyczy to także okresu sąsiadującego ze świętem. Warto pamiętać, że w przypadku imion mających odniesienie hagiograficzne, święty jest wspominany w swoim właściwym dniu, tj. w dniu dies natalis. Był to dzień śmierci świętego, ale równocześnie dzień narodzin dla nieba.

${ }^{8}$ Motywy jakimi kierują się rodzice przy wyborze imienia ulegają zmianom. W badaniach prowadzonych w latach $70 \mathrm{XX}$ wieku na pierwszym miejscu wymieniano: motywację estetyczną, czyli ładne brzmienie form zdrobniałych imienia oraz współbrzmienie z nazwiskiem. Malec, Imię w polskiej antroponimii, s. 80. Zob. też: J. Bubak, Księga naszych imion, Wrocław 1993.

${ }^{9}$ AP, Liber memorabilium, bns. Autor kroniki, ks. Andrzej Ujejski, wylicza jeszcze 8 innych profesji.

${ }^{10}$ W. Schenk, Chrzest II. Liturgia, w: Encyklopedia Katolicka, t. 3, Lublin 1985, kol. 362-364. 


\section{Imiona męskie}

W celu pokazania ich różnorodności oraz częstotliwości występowania, podzielono wszystkie nadane w Iskrzyni imiona na trzy grupy. Pierwsza z nich, to imiona najczęściej używane (przynajmniej 3\% w ogólnej liczbie zapisów), druga to imiona średnio popularne (od $1 \%$ do niespełna $3 \%$ ) oraz używane sporadycznie (poniżej $1 \%)^{11}$. Dodatkowo, cały badany okres rozbito na pięć przedziałów czasowych $^{12}$.

Tabela 1. Częstotliwość nadawania imion męskich

\begin{tabular}{|c|c|c|c|c|c|c|c|c|c|c|c|c|c|}
\hline \multirow{2}{*}{ Imię } & \multicolumn{2}{|c|}{$1848-1860$} & \multicolumn{2}{|c|}{$1861-1870$} & \multicolumn{2}{|c|}{$1871-1880$} & \multicolumn{2}{|c|}{$1881-1890$} & \multicolumn{2}{|c|}{$1891-1900$} & \multicolumn{3}{|c|}{$1848-1900$} \\
\hline & 1 & 2 & 1 & 2 & 1 & 2 & 1 & 2 & 1 & 2 & 2 & L.b. & Sz.s. \\
\hline 1 & 2 & 3 & 4 & 5 & 6 & 7 & 8 & 9 & 10 & 11 & 12 & 13 & 14 \\
\hline Jan & 27,9 & 25,2 & 21,4 & 24,1 & 19,5 & 19,4 & 14,9 & 14,2 & 16,2 & 16 & 19,7 & 154 & 154 \\
\hline Stanisław & 8 & 3,5 & 13,3 & 7,3 & 22,7 & 11 & 22,7 & 10,5 & 33,3 & 16 & 9,6 & 75 & 229 \\
\hline Franciszek & 20,9 & 8,2 & 19,4 & 9,5 & 19,4 & 8,4 & 19,4 & 8 & 20,9 & 9 & 8,6 & 67 & 296 \\
\hline Józef & 21,5 & 8,2 & 10,8 & 5,1 & 15,4 & 6,5 & 24,6 & 9,9 & 27,7 & 11,5 & 8,3 & 65 & 361 \\
\hline Paweł & 23,7 & 8,2 & 15,3 & 6,6 & 27,1 & 10,3 & 17 & 6,2 & 17 & 6,4 & 7,6 & 59 & 420 \\
\hline Wojciech & 22 & 6,4 & 22 & 8 & 28 & 9 & 14 & 4,3 & 14 & 4,5 & 6,4 & 50 & 470 \\
\hline Michał & 35,3 & 7 & 17,7 & 4,4 & 23,5 & 5,2 & 11,8 & 2,5 & 11,8 & 2,6 & 4,4 & 34 & 504 \\
\hline Jakub & 30,8 & 4,7 & 19,2 & 3,7 & 19,2 & 3,2 & 23,1 & 3,7 & 7,7 & 1,3 & 3,3 & 26 & 530 \\
\hline Antoni & 37,5 & 5,3 & 29,2 & 5,1 & 20,8 & 3,2 & 8,3 & 1,2 & 4,2 & 0,6 & 3,1 & 24 & 554 \\
\hline Władysław & 4,6 & 0,6 & & & 13,6 & 1,9 & 22,7 & 3,1 & 59 & 8,3 & 2,8 & 22 & 576 \\
\hline Andrzej & 33,3 & 4,1 & 28,6 & 4,4 & 9,5 & 1,3 & & & 28,6 & 3,9 & 2,7 & 21 & 597 \\
\hline Piotr & 25 & 2,3 & 12,5 & 1,5 & 12,5 & 1,3 & 25 & 2,5 & 25 & 2,6 & 2,1 & 16 & 613 \\
\hline Tomasz & 40 & 3,5 & 20 & 2,2 & 6,7 & 0,7 & 26,7 & 2,5 & 6,7 & 0,6 & 1,9 & 15 & 628 \\
\hline Maciej & 21,4 & 1,8 & 14,3 & 1,5 & 28,6 & 2,6 & 28,6 & 2,5 & 7,1 & 0,6 & 1,8 & 14 & 642 \\
\hline Kazimierz & 15,4 & 1,2 & 61,5 & 5,8 & 7,7 & 0,7 & 7,7 & 0,6 & 7,7 & 0,6 & 1,7 & 13 & 655 \\
\hline Roman & & & & & 61,5 & 5,2 & 38,5 & 3,1 & & & 1,7 & 13 & 668 \\
\hline Marcin & 40 & 2,3 & 20 & 1,5 & 10 & 0,7 & 20 & 1,2 & 10 & 0,6 & 1,3 & 10 & 678 \\
\hline Gerard & & & & & & & 12,5 & 0,6 & 87,5 & 4,5 & 1 & 8 & 686 \\
\hline Henryk & 12,5 & 0,6 & & & 37,5 & 1,9 & 37,5 & 1,9 & 37,5 & 0,6 & 1 & 8 & 694 \\
\hline Ignacy & & & & & 12,5 & 0,7 & 50 & 2,5 & 37,5 & 1,9 & 1 & 8 & 702 \\
\hline Wawrzyniec & 25 & 1,2 & 25 & 1,5 & 1,9 & 1,9 & 12,5 & 0,6 & & & 1 & 8 & 710 \\
\hline Grzegorz & 50 & 1,8 & 16,7 & 0,7 & & & 33,3 & 1,2 & & & 0,8 & 6 & 716 \\
\hline Karol & & & & & & & 33,3 & 1,2 & 66,6 & 2,6 & 0,8 & 6 & 722 \\
\hline Wincenty & 16,7 & 0,6 & & & & & 83,3 & 3,1 & & & 0,8 & 6 & 728 \\
\hline Błażej & & & 25 & 0,7 & 25 & 0,7 & 25 & 0,6 & 25 & 0,6 & 0,5 & 4 & 732 \\
\hline Feliks & & & 33,3 & 0,7 & 33,3 & 0,7 & 33,3 & 0,6 & & & 0,4 & 3 & 735 \\
\hline Leon & & & 33,3 & 0,7 & 33,3 & 0,7 & 33,3 & 0,6 & & & 0,4 & 3 & 738 \\
\hline Szymon & 33,3 & 0,6 & 33,3 & 0,7 & & & & & 33,3 & 0,6 & 0,4 & 3 & 741 \\
\hline Wiktor & 33,3 & 0,6 & 66,6 & 1,5 & & & & & & & 0,4 & 3 & 744 \\
\hline Aleksy & & & & & 50 & 0,7 & 50 & 0,6 & & & 0,3 & 2 & 746 \\
\hline
\end{tabular}

${ }^{11}$ Por. Sułowski, Imiona chrzestne w parafii, s. 103.

${ }^{12}$ Zapisy w metrykach sporządzane były w języku łacińskim, imiona zestawione w tabelach przedstawiono $\mathrm{w}$ ich polskiej formie. 


\begin{tabular}{|c|c|c|c|c|c|c|c|c|c|c|c|c|c|}
\hline 1 & 2 & 3 & 4 & 5 & 6 & 7 & 8 & 9 & 10 & 11 & 12 & 13 & 14 \\
\hline Bronisław & & & & & 50 & 0,7 & & & 50 & 0,6 & 0,3 & 2 & 748 \\
\hline Edward & & & 50 & 0,7 & & & 50 & 0,6 & & & 0,3 & 2 & 750 \\
\hline Filip & & & & & & & 50 & 0,6 & 50 & 0,6 & 0,3 & 2 & 752 \\
\hline Hiacynt & & & 50 & 0,7 & & & 50 & 0,6 & & & 0,3 & 2 & 754 \\
\hline Izydor & & & & & & & 100 & 1,2 & & & 0,3 & 2 & 756 \\
\hline Wacław & & & 100 & 0,7 & & & & & & & 0,3 & 2 & 758 \\
\hline Adam & 100 & 0,6 & & & & & & & & & 0,1 & 1 & 759 \\
\hline Aleksander & & & 100 & 0,7 & & & & & & & 0,1 & 1 & 760 \\
\hline Bartłomiej & & & & & & & 100 & 0,6 & & & 0,1 & 1 & 761 \\
\hline Bolesław & & & & & & & & & 100 & 0,6 & 0,1 & 1 & 762 \\
\hline Cyprian & & & & & 100 & 0,7 & & & & & 0,1 & 1 & 763 \\
\hline Czesław & & & & & & & & & 100 & 0,6 & 0,1 & 1 & 764 \\
\hline Eustachy & & & & & & & 100 & 0,6 & & & 0,1 & 1 & 765 \\
\hline Florian & & & & & & & 100 & 0,6 & & & 0,1 & 1 & 766 \\
\hline Kacper & & & & & 100 & 0,7 & & & & & 0,1 & 1 & 767 \\
\hline Hipolit & & & & & 100 & 0,7 & & & & & 0,1 & 1 & 768 \\
\hline Joachim & & & & & & & 100 & 0,6 & & & 0,1 & 1 & 769 \\
\hline Juliusz & & & & & & & 100 & 0,6 & & & 0,1 & 1 & 770 \\
\hline Konstanty & & & & & & & 100 & 0,6 & & & 0,1 & 1 & 771 \\
\hline Łukasz & 100 & 0,6 & & & & & & & & & 0,1 & 1 & 772 \\
\hline Marek & 100 & 0,6 & & & & & & & & & 0,1 & 1 & 773 \\
\hline Mieczysław & & & & & & & & & 100 & 0,6 & 0,1 & 1 & 774 \\
\hline Mikołaj & & & & & & & 100 & 0,6 & & & 0,1 & 1 & 775 \\
\hline Onufry & & & & & & & 100 & 0,6 & & & 0,1 & 1 & 776 \\
\hline Rafał & & & & & & & 100 & 0,6 & & & 0,1 & 1 & 777 \\
\hline Roch & & & & & & & 100 & 0,6 & & & 0,1 & 1 & 778 \\
\hline Rudolf & & & & & & & 100 & 0,6 & & & 0,1 & 1 & 779 \\
\hline Sebastian & & & & & & & 100 & 0,6 & & & 0,1 & 1 & 780 \\
\hline Walenty & 100 & 0,6 & & & & & & & & & 0,1 & 1 & 781 \\
\hline
\end{tabular}

Źródło: AP, Księga urodzeń (ochrzczonych) 1841-1889, 1890-1906. 1-\% imienia w danym okresie do ogólnej liczby danego imienia; 2- \% danego imienia do ogólnej liczby imion w danym przedziale czasowym. Sz. s. - szereg skumulowany.

W latach 1848-1900 nadano ogółem na chrzcie 59 imion męskich (w chrztach „,wieloimiennych” brano pod uwagę imię pierwsze). Spośród nich ponad 70\% stanowiła grupa dziewięciu wybieranych najczęściej (udział przynajmniej 3\%). Imiona nadawane rzadziej (od 1 do 3\%) stanowiły $20 \%$ ogółu imion chrzestnych. W zbiorze tym wyodrębniono 12 antroponimów. Wreszcie, ostatnią grupę tworzyły imiona pojawiające się w metrykach sporadycznie (poniżej $1 \%$ ), a ich odsetek w odniesieniu do całości kształtował się na poziomie $9 \%$. Grupa ta była najbogatsza pod względem różnorodności - 38 imion (patrz tabela 1).

Rozbijając badany okres na pięć przedziałów czasowych, możemy prześledzić w całym badanym okresie strukturę nadawanych imion, czyli tych, które cechuje długie trwanie i duża częstotliwość występowania, oraz prześledzić pewne zmiany w nadawaniu imion chrzestnych, zwłaszcza zjawisko pojawiania się nowych 
imion $^{13}$. I tak, w pierwszym przekroju odnotowano 26 imion, podobnie jak w następnym, z tym, że w porównaniu z poprzednim okresem pojawiło się siedem nowych. Należy również zwrócić uwagę na fakt, iż w latach 1848-1860 na świat przyszło 171 noworodków płci męskiej, natomiast w następnym dziesięcioleciu o 34 dzieci mniej, a co za tym idzie i różnorodność nadawanych imion była większa. W trzecim przedziale czasowym stwierdzono 28 typów imion, a więc wzrost w stosunku do dwóch pierwszych okresów. Pojawiło się także 7 nowych imion. Lata 1881-1890 to znaczny progres pod względem zróżnicowania w wybieranych imionach dla noworodków. Zanotowano ich 33, o pięć więcej niż w poprzednim przekroju. Dodatkowo nie wiązało się to ze znaczniejszym wzrostem w liczbie urodzonych (różnica 7 urodzeń). Dużo bogatszy był także repertuar wybieranych imion, wynikający z pojawienia się 16 nowych, które nie występowały wcześniej. Znaczny regres pod tym względem stwierdzono dla ostatniej dekady XIX wieku. Wyodrębniono dla niej zaledwie 27 imion, a wśród nich były tylko 3, których nie odnotowano w poprzednich latach.

Ogólnie więc, wzrost liczby nadawanych imion łączył się ze spadkiem popularności imion najczęstszych ${ }^{14}$. Najwyższy odsetek stwierdzono dla pierwszego okresu $-76,7 \%$, a najniższy w latach osiemdziesiątych XIX wieku- $60,5 \%$. W ostatniej dekadzie tego wieku nastąpił wzrost, ale i tak nie przekroczył $70 \%$. Tendencja zwyżkowa miała natomiast miejsce wśród imion zaliczonych do drugiej grupy ( z 17,6\% do 24,2\%). Nieco większe wahania wystąpiły dla imion pojawiających się sporadycznie, przy czym najniższy odsetek zanotowano również w pierwszym okresie $-6 \%$, najwyższy natomiast w latach 1881-1890.

Analiza imion wykazała ${ }^{15}$, że najczęściej nadawanym imieniem męskim był Jan $^{16}$ (otrzymał je co piąty chłopiec). Na drugim miejscu znalazł się Stanisław (niespełna $10 \%$ ) a na trzecim Franciszek $(8,6 \%)$. Na ostatnim miejscu wśród imion, które zostały zaliczone do kategorii najczęstszych, był Antoni (3,1\%). W wyborze tych imion w poszczególnych okresach zachodziły zmiany. Odsetek imienia Jan zmniejszył się z 27,9\% do $14,9 \%$ w latach $1881-1890$. W ostatnim dziesięcioleciu XIX wieku odnotowano znów wzrost, ale różnica w stosunku do

${ }^{13} \mathrm{~W}$ średniowieczu różnorodność imion była duża, następnie w stuleciach XV-XVII miało miejsce większe ich ujednolicenie, poczynając zaś od wieku XVIII wachlarz imion zaczął się rozszerzać. Z. Sułowski, Imiona chrzestne w Polsce XIV-XIX w., „Sprawozdania z Czynności Wydawniczej Posiedzeń Naukowych oraz Kronika Towarzystwa Naukowego KUL”, 11 (1961), s. 95-96.

${ }_{14}$ Zob. J. Gawrysiakowa, Zwyczaje chrzestne na Lubelszczyźnie w XIX wieku, „Novum”, 1 (1980) s 92-93; Sułowski, Imiona chrzestne w parafii, s. 102-103.

${ }^{15}$ Oprócz wyżej wspominanych motywów wyboru imienia, ważną rolę odgrywało duchowieństwo. Mając duży wpływ, szczególnie w społeczności wiejskiej, często o nadaniu konkretnego imienia decydowało za rodziców. , Trzeba również pamiętać, że skwapliwie nad tym czuwali duchowni, aby dzieciom na chrzcie nadawać imiona z kalendarza kościelnego. Nawet jeszcze na pocz. XX w. imię naszego pierwszego króla było odradzane, ze względu na skojarzenie z zabójstwem św. Stanisława" W. Baranowski, Kult świętych nie uznawanych przez władze kościelne w katolicyzmie ludowym, „Euhemer. Przegląd Religioznawczy”, 79 (1971) nr 1, s. 51; Zob. też J. S. Bystroń, Księga imion w Polsce używanych, Warszawa 1938, s. 26.

${ }^{16}$ Imię Jan rozpowszechniło się już w średniowiecznej Polsce. M. Malec, Imiona chrześcijańskie w średniowiecznej Polsce, Kraków 1994, s. 243. 
odsetka w pierwszym okresie wynosiła ponad $11 \%$. Charakterystyczny był ciągły progres w nadawaniu imienia Stanisław (od 8\% w latach 1848-1860 do 33,3\% w latach dziewięćdziesiątych). W sumie, w latach 1891-1900 procentowy udział tego imienia w odniesieniu do wszystkich pozostałych był taki sam jak Jana (po $16 \%$ ). Na uwagę zwraca także rosnący wraz z upływem czasu odsetek imienia Józef (od 8,2\% do $11,5 \%)^{17}$.

Spośród imion zaliczonych do przedziału 1\%-3\%, wyróżnia się Władysław. W latach 1861-1870 nie zanotowano ani jednego ochrzczonego dziecka tym imieniem, jednak już od następnego dziesięciolecia nastąpił stały wzrost, by w ostatniej dekadzie osiągnąć ponad $8 \%$ wśród wszystkich nadanych imion. Na komentarz zasługuje również imię Gerard. W pierwszych trzech przekrojach nie wystąpiło ono w ogóle. W latach 1881-1890 ochrzczono tylko jedno dziecko tym imieniem, za to w następnym dziesięcioleciu odnotowano już siedem takich przypadków, co stanowiło 4,5\% ogólnej liczby w tym okresie. W grupie tej znalazł się także Andrzej i Roman.

Obserwując częstotliwość występowania tych dwóch imion, możemy stwierdzić związek z imieniem aktualnie urzędującego proboszcza. Na przestrzeni pięćdziesięciu trzech lat, które poddaliśmy analizie, funkcję proboszcza w Krościenku Wyżnym pełniło trzech kapłanów. Byli to kolejno: Andrzej Nowina Ujejski (od 1831 do 1867), Roman Pakosz Piekosiński (od 1867 do 1887) i Wincenty Telega (od 1887 do 1919) ${ }^{18}$. Maksimum chłopców, którym na chrzcie nadano imię Andrzej przypadło na lata 1848-1860 (33,3\%). Niewiele mniej odnotowano w następnym dziesięcioleciu $(28,6 \%)$. W kolejnym przedziale było to zaledwie $9,5 \%$, a w latach osiemdziesiątych nie stwierdzono ani jednego chrztu tym imieniem. Tego typu zależność widać jeszcze wyraźniej na przykładzie noworodków, którym nadano imię Roman. Pojawiło się ono tylko w dwóch przekrojach, to jest 1871-1880 i 1881-1890, co dokładnie odpowiada okresowi posługi Romana Piekosińskiego. Analogiczną zależność jak w poprzednich dwóch wypadkach można dostrzec przy wyborze imienia Wincenty.

Osobny problem stanowi nadawanie dzieciom kilku imion. W latach 18481900 podwójne imię na chrzcie otrzymało 33 chłopców, co stanowiło 4,2\% wszystkich imion męskich ${ }^{19}$. Charakterystyczne było to, że pierwszy taki chrzest

${ }^{17}$ Do imion najpopularniejszych w parafii Piotrawin na Lubelszczyźnie w latach 1815-1817 należały Jan, Stanisław i Józef. Z. Sułowski, dz. cyt., s. 102; Również w badaniach przeprowadzonych na terenie parafii lubelskich imiona te były bardzo modne. Do najchętniej nadawanych na chrzcie imion należały; Jan, Józef, Antoni, Michał, Franciszek i Stanisław. Były to więc takie same imiona jak w Iskrzyni. Gawrysiakowa, Zwyczaje, s. 88. W parafii kochłowickiej leżącej na Śląsku, skład imion zaliczanych do najczęściej nadawanych był podobny. Na osiem wyodrębnionych w tej grupie aż sześć było takich samych jak w analogicznej grupie w Iskrzyni (były to: Jan, Jakub, Franciszek, Paweł, Józef i Antoni. P. Kwapulińska, Urodzenia w parafii kochtowickiej w XIX wieku, „Śląskie Studia Demograficzne. Prace Historyczne”, 14 (1995) s. 49. Por. też S. Dziadkowiec, Imiona mieszkańców wsi Pcim i motywacje ich nadawania w latach 1617-1899 oraz wspótcześnie, „Onomastica", 45 (2000) s 180-184;

${ }^{18}$ R. Pelczar, Dzieje Krościenka Wyżnego 1350-2000, Krościenko Wyżne, s. 179-181.

${ }^{19} \mathrm{Z}$ powodu małej liczby imion podwójnych zagadnienia tego nie poddaliśmy głębszej analizie. O imionach wielorakich zob. m. in. A. Tomecka, Imiona chrzestne w księgach metrykalnych 
miał miejsce dopiero w 1865 roku. Zdecydowaną większość imion podwójnych nadano w latach osiemdziesiątych (prawie $82 \%$ ), po czym nastąpił spadek (nadano tylko dwa takie imiona, co stanowiło 6\%). Rozkład ten należy zapewne tłumaczyć panującą okresowo modą ${ }^{20}$.

Z czynników mających wpływ na nadawanie imion na czoło wysuwa się związek daty chrztu i święta patrona ${ }^{21}$. Podobnie jak przy badaniu częstotliwości nadawanych imion, ułożono je w kolejności od najczęstszych do występujących sporadycznie; w przypadku takiej samej liczby decydowała kolejność alfabetyczna (tabela 2).

Tabela 2. Sezonowość nadawania imion męskich

\begin{tabular}{|c|c|c|c|c|c|c|c|c|c|c|c|c|c|c|c|}
\hline \multirow[b]{2}{*}{ Imię i data święta* } & \multicolumn{12}{|c|}{ Miesiące } & \multirow[b]{2}{*}{$\begin{array}{l}\text { Eี } \\
\widetilde{N} \\
\widetilde{\simeq}\end{array}$} & \multirow{2}{*}{ 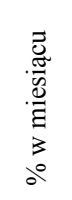 } & \multirow[b]{2}{*}{$\begin{array}{l}\frac{0}{\pi} \\
\frac{\pi}{\pi} \\
\frac{3}{3} \\
\frac{3}{3} \\
0^{\circ}\end{array}$} \\
\hline & 芯 & $\stackrel{2}{\vdots}$ & $\begin{array}{l}\stackrel{\mathscr{J}}{N} \\
\stackrel{\mathbb{U}}{\Xi}\end{array}$ & 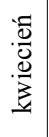 & ت্] & 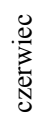 & : & 离 & 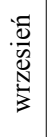 & 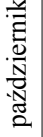 & 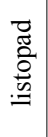 & 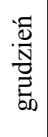 & & & \\
\hline 1 & 2 & 3 & 4 & 5 & 6 & 7 & 8 & 9 & 10 & 11 & 12 & 13 & 14 & 15 & 16 \\
\hline Jan 16 V, 24 VI, 27 XII & 13 & 8 & 13 & 14 & 25 & 17 & 9 & 9 & 6 & 9 & 4 & 27 & 154 & 44,8 & 62,3 \\
\hline Stanisław $8 \mathrm{~V}$ & 7 & 5 & 1 & 13 & 17 & 4 & 5 & 5 & 5 & 2 & 7 & 4 & 75 & 22,7 & 45,3 \\
\hline Franciszek $10 \mathrm{X}$ & 8 & 2 & 13 & 2 & 3 & 1 & 2 & 4 & 18 & 7 & 3 & 4 & 67 & 10,5 & 41,8 \\
\hline Józef 19 III & 4 & 12 & 26 & 2 & & 4 & 2 & 2 & 3 & 3 & 2 & 5 & 65 & 40 & 61,1 \\
\hline Paweł 15 I, 29 VI & 25 & 5 & 2 & & 2 & 6 & 4 & 3 & 4 & 2 & 2 & 4 & 59 & 52,5 & 78 \\
\hline Wojciech 23 IV & & 2 & 8 & 32 & 1 & 1 & 2 & & 1 & & 2 & 1 & 50 & 64 & 82 \\
\hline Michał 29 IX & & & & & & 1 & 1 & 7 & 23 & 2 & & & 34 & 67,7 & 94 \\
\hline Jakub 1 V 25 VII & & & & 1 & & 1 & 24 & & & & & & 26 & 92,3 & 100 \\
\hline Antoni $17 \mathrm{I}, 10 \mathrm{~V}, 13 \mathrm{VI}$ & 1 & & & & 5 & 18 & & & & & & & 24 & 100 & 100 \\
\hline Władysław 27.VI & 2 & & 2 & 2 & 4 & 6 & & & 2 & 2 & & 2 & 22 & 27,3 & 45,5 \\
\hline Andrzej 30.XI & & & & 1 & & & & 1 & 1 & 1 & 13 & 4 & 21 & 61,9 & 85,7 \\
\hline Piotr 29.VI & & & & 1 & 3 & 10 & & & & & 1 & 1 & 16 & 62,5 & 81,3 \\
\hline Tomasz 21.XII & & & 1 & & & & & & 1 & & 2 & 11 & 15 & 73,3 & 86,7 \\
\hline
\end{tabular}

Nowej Brzeźnicy k. Częstochowy w XVII i XVIII wieku, „Onomastica”, 39 (1994) s. 167; M. Stachurska, Wieloimienność na podstawie metryk parafialnych Miechowa (1826-1829), „Onomastica”, 39 (1994) s. 179.

${ }^{20}$ „W osiemnastym wieku wraz z coraz to silniejszym wzmaganiem się dewocji, zwyczaj nadawania dzieciom kilku imion stał się dość powszechny; chodziło tu o to, by zapewnić chrześniakowi łaskawą protekcję kilku świętych patronów, a zarazem by pozyskać łaski kilku ziemskich protektorów" (Bystroń, Księga imion w Polsce, s. 48).

${ }^{21}$ „Na imiona chrzestne wybierają rodzice albo tych świętych, w których dniu dziecię przyszło na świat, albo w których dniu było ochrzczone. Święty, pod którego wezwaniem jest kościół parafialny, jest również często nadawany jako imię chrzestne. Często rodzeństwo (bracia i siostry) wybierają imię nowonarodzonego braciszka bądź siostrzyczki, a rodzice na to się zgadzają, aby starsze rodzeństwo przyjęło mile nowoprzybyłego" (W. Sarna, Opis powiatu krośnieńskiego pod względem geograficzno-historycznym, Przemyśl 1898, s. 123). „Zwyczaj powszechny nakazywał wybierać imiona, które dziecko przyniosło w dzień urodzenia [...]. Oczywiście w kalendarzu liturgicznym figurowały imiona świętych, którzy byli nie znani szerszemu ogółowi, więc wówczas wybierano dziecku patrona, którego święto było w pobliżu" (Tamże, s. 68). 


\begin{tabular}{|c|c|c|c|c|c|c|c|c|c|c|c|c|c|c|c|}
\hline 1 & 2 & 3 & 4 & 5 & 6 & 7 & 8 & 9 & 10 & 11 & 12 & 13 & 14 & 15 & 16 \\
\hline Maciej 24 II & 1 & 12 & 1 & & & & & & & & & & 14 & 85,7 & 100 \\
\hline Kazimierz 4.III & 1 & 3 & 6 & & 1 & 1 & & & 1 & & & & 13 & 46,2 & 69,2 \\
\hline Roman 28.II & 2 & 4 & 1 & & 2 & & & 3 & 1 & & & & 13 & 30,8 & 53,9 \\
\hline Marcin 11.XI & & & & & & & & & 1 & 1 & 8 & & 10 & 80 & 90 \\
\hline Gerard 24.IX & & 1 & 2 & 1 & 1 & 1 & & & 1 & 1 & & & 8 & 12,5 & 25 \\
\hline Henryk 19.I, 15.VII & 2 & & & & & & & 2 & 1 & & 3 & & 8 & 25 & 50 \\
\hline Ignacy 1.II, 31.VII & 1 & 2 & 1 & 1 & & & 3 & & & & & & 8 & 25 & 50 \\
\hline Wawrzyniec 10.VIII & 2 & & & & & 2 & 2 & 2 & & & & & 8 & 25 & 50 \\
\hline Grzegorz 12.III & & & 4 & & 1 & & 1 & & & & & & 6 & 66,7 & 66,7 \\
\hline Karol 4.XI & 1 & & & 1 & & & 1 & 1 & & & 2 & & 6 & 33,3 & 33,3 \\
\hline Wincenty 18 .VII & & & 1 & 1 & & 2 & 2 & & & & & & 6 & 33,3 & 66,7 \\
\hline Błażej 3.II & 1 & 1 & & 1 & & & & & & 1 & & & 4 & 25 & 50 \\
\hline Feliks 14.I & 2 & & & & 1 & & & & & & & & 3 & 66,7 & 66,7 \\
\hline Leon 11.IV & & 2 & & 1 & & & & & & & & & 3 & 33,3 & 33,3 \\
\hline Szymon $28 . X$ & & & & & & & & & & 3 & & & 3 & 100 & 100 \\
\hline Wiktor 1.IX & & & & & 1 & & 1 & & 1 & & & & 3 & 33,3 & 33,3 \\
\hline Aleksy 17.VII & & & & & & & 2 & & & & & & 2 & 100 & 100 \\
\hline Bronisław 1.IX & & 1 & & & & & 1 & & & & & & 2 & & \\
\hline Edward 13.X & & & & & & & & & & 2 & & & 2 & 100 & 100 \\
\hline Filip 1.V & & & & & 1 & & & 1 & & & & & 2 & 50 & 50 \\
\hline Hiacynt 16.III & & & & & & & 2 & & & & & & 2 & & \\
\hline Izydor 4.IV & & & & 1 & & & & & & & 1 & & 2 & 50 & 50 \\
\hline Wacław 29.IX & & & & 1 & & & & & 1 & & & & 2 & 50 & 50 \\
\hline Adam 24.XII & & & & & & & & & & 1 & & & 1 & & \\
\hline Aleksander 26.II & & 1 & & & & & & & & & & & 1 & 100 & 100 \\
\hline Bartłomiej 14.VIII & & & & & & & & 1 & & & & & 1 & 100 & 100 \\
\hline Bolesław 19.VIII & & & & & 1 & & & & & & & & 1 & & \\
\hline Cyprian 16.IX & & & & & & & & & 1 & & & & 1 & 100 & 100 \\
\hline Czesław 2.IX & & & & & & & & & 1 & & & & 1 & 100 & 100 \\
\hline Eustachy 20.IX & & & 1 & & & & & & & & & & 1 & & \\
\hline Florian 4.V & & & & & 1 & & & & & & & & 1 & 100 & 100 \\
\hline Kacper 6.I & & & & & & & & 1 & & & & & 1 & & \\
\hline Hipolit 13.VIII & & & & & & & & 1 & & & & & 1 & 100 & 100 \\
\hline Joachim 3.IX & & & & & & & & & 1 & & & & 1 & 100 & 100 \\
\hline Juliusz 12.IV & & & & & & & & & 1 & & & & 1 & & \\
\hline Konstanty 11.III & & & 1 & & & & & & & & & & 1 & 100 & 100 \\
\hline Łukasz 18.X & & & & & & & & & & 1 & & & 1 & 100 & 100 \\
\hline Marek 24.III & & & 1 & & & & & & & & & & 1 & 100 & 100 \\
\hline Mieczysław 1.I & & & & & & & & & & & 1 & & 1 & & \\
\hline Mikołaj 6.XII & & & & & & & & & & & & 1 & 1 & 100 & 100 \\
\hline Onufry $12 . \mathrm{VI}$ & & & & & & & & & & & 1 & & 1 & & \\
\hline Rafał 24.X & & & & & & & & & & 1 & & & 1 & 100 & 100 \\
\hline Roch 16.VIII & & & & & & & & 1 & & & & & 1 & 100 & 100 \\
\hline Rudolf 17.IV & & 1 & & & & & & & & & & & 1 & & \\
\hline Sebastian 20.I & 1 & & & & & & & & & & & & 1 & 100 & 100 \\
\hline Walenty 14.II & 1 & & & & & & & & & & & & 1 & & 100 \\
\hline Razem & 75 & 62 & 85 & 76 & 70 & 75 & 65 & 43 & 75 & 39 & 52 & 64 & 781 & $\mathrm{x}$ & $\mathrm{x}$ \\
\hline
\end{tabular}




\begin{tabular}{|c|c|c|c|c|c|c|c|c|c|c|c|c|c|c|c|}
\hline 1 & 2 & 3 & 4 & 5 & 6 & 7 & 8 & 9 & 10 & 11 & 12 & 13 & 14 & 15 & 16 \\
\hline W miesiącu święta & 31 & 20 & 38 & 34 & 49 & 57 & 31 & 5 & 29 & 14 & 23 & 39 & $\mathrm{x}$ & 370 & 582 \\
\hline \% w miesiącu święta & $\stackrel{m}{f}$ & $\stackrel{n}{\sim}$ & $\stackrel{f}{f}$ & $\stackrel{f}{f}$ & 웅 & 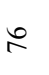 & $\hat{\widetilde{f}}$ & $\stackrel{0}{=}$ & $\vec{\infty}$ & जे & $\begin{array}{l}\text { f } \\
\text { f }\end{array}$ & $\hat{\theta}$ & $\mathrm{x}$ & 47,4 & 74,5 \\
\hline
\end{tabular}

Źródło: AP, Księga urodzeń (ochrzczonych) 1841-1889, 1890-1906.

* Daty świąt ustalono na podstawie Kalendarza Ilustrowanego na rok 1876, autorstwa Jana Jaworskiego. Wykorzystano również: B. Kupis, B. Wernichowska, J. Kamyczek, Księga Imion, Warszawa 1975.

W całym przebadanym okresie, ponad $47 \%$ chłopców otrzymało imiona patronów, których święta przypadały w miesiącu udzielania chrztu. Gdyby rozszerzyć ten okres o miesiąc poprzedzający święto i następujący po nim, wówczas odsetek imion chrzestnych nadanych w kwartale święta wyniesie 74,5\%. Szesnaście z wymienionych w tabeli imion nadano wyłącznie w miesiącu święta. Były to jednak imiona, które pojawily się tylko jeden lub dwa razy.

Spośród dziewięciu imion zaliczonych do kategorii najpopularniejszych, trzy, tj. Jan, Stanisław i Franciszek były nadawane przez cały $\operatorname{rok}^{22}$. Największe nasilenie dzieci ochrzczonych tym pierwszym imieniem przypadało na miesiące: maj - święto Jana Nepomucena (16,2\%), czerwiec - Jana Chrzciciela (11\%) i grudzień - Jana Ewangelisty (17,5\%), tutaj też należało by prawdopodobnie zaliczyć chrzty ze stycznia. Dziwi trochę stosunkowo niski odsetek tego imienia w lipcu $(5,8 \%)$, bowiem jedenastego tego miesiąca przypadało wspomnienie lokalnego patron Jana z Dukli. Natomiast o częstym wyborze Jana Nepomucena na patrona, decydowały zapewne czynniki lokalne. Kult tego świętego cieszył się w parafii Krościenko Wyżne niesłabnącą siłą od XVIII w. W 1744 r. J. Kuźnar ufundował obraz św. Jana Nepomucena do ołtarza bocznego kościoła parafialnego, a w 1843 r. proboszcz ks. A. Ujejski ufundował kapliczkę ku czci tego świętego. W święto Jana Nepomucena podobnie jak na św. Marcina, w parafii odbywały się tak zwane ,kramarki”. Dzieci na długo wcześniej składały pieniądze aby coś kupić na odpuście. Cały dzień było słychać muzykę na trąbkach, drumlach, fujarkach, organkach $^{23}$.

Największy odsetek chłopców, którzy na chrzcie otrzymali imię Stanisław przypadł w maju (22,7\%), a więc w miesiącu upamiętniającym św. Stanisława biskupa. Maj jest także jednym z pierwszym pod względem odsetka nadanych imion w miesiącu święta głównego patrona (ok. 63\%). Pewne przesunięcie w liczbie nadanych imion w stosunku do daty święta miało miejsce w przypadku Franciszka. Maksimum przypadło tu we wrześniu (26,9\%), zatem w miesiącu poprzedzającym wspomnienie Franciszka Borgiasza (być może na wybór tego imienia decydowano się ,do przodu” pamiętając o październikowym święcie). Maksimum imienia Józef przypadło na marzec, czyli pamiątkę wspomnienia Oblubieńca N.M.P. W przypadku imienia Paweł największy odsetek przypadł na

${ }^{22}$ Por. Gawrysiakowa, Zwyczaje chrzestne, s. 90-91; Sułowski, Imiona chrzestne w parafii, s. $110-114$.

${ }^{23} \mathrm{AP}$, Liber memorabilium, bns. 
styczeń - wspomnienie pierwszego pustelnika. Święto to było bardziej rozpowszechnione aniżeli czerwcowe. Do chętnie wybieranych na chrzcie patronów należał także św. Wojciech. Procentowy udział kwietnia wyniósł 64\% (wspomnienie świętego obchodzimy 23 IV). Podobna sytuacja miała miejsce w odniesieniu do pozostałych trzech imion zaliczonych do grupy najczęściej występujących. W święto Michała Archanioła (29 IX) nadano prawie $68 \%$ wszystkich Michałów. Jeszcze wyraźniejszy udział głównego święta patrona widać na przykładzie Jakuba, kiedy to w lipcu (25 VII - Jakuba Apostoła) odsetek wyniósł ponad $92 \%$ oraz św. Marcina - patrona parafii $(80 \%)$. Uwagę zwracają również przejawy kultu Antoniego Padewskiego (13 VI), Piotra (29 VI) oraz Macieja (25 II). W przypadku Antoniego chrzty z czerwca stanowiły $75 \%$. Niewykluczone, że dzieci chrzczone tym imieniem w maju $(20,8 \%)$ były powierzane właśnie temu patronowi. Ponad $85 \%$ chłopców o imieniu Maciej było chrzczonych w lutym. Miesiąc ten miał najwyższy odsetek nadanych imion $\mathrm{w}$ odniesieniu do święta patrona. Wiązało się to prawdopodobnie z brakiem w tym miesiącu uroczystości ku czci innych popularnych świętych.

W sumie widać, że najbardziej prawdopodobnym powodem wyboru imienia na chrzcie był aktualny okres roku liturgicznego; w porównaniu z wpływem kalendarza kościelnego inne czynniki (np. nadanie imienia po ojcu lub rodzicach chrzestnych) miały drugorzędne znaczenie.

\section{Imiona żeńskie}

Rodzajów imion żeńskich było mniej niż męskich (tabela 3), jednak i liczba ochrzczonych dziewczynek była mniejsza. Po podzieleniu liczby noworodków płci męskiej przez liczbę występujących imion otrzymamy ten sam stosunek jak dla noworodków płci żeńskiej - 13,2.

Tabela 3. Częstotliwość nadawania imion żeńskich

\begin{tabular}{|c|c|c|c|c|c|c|c|c|c|c|c|c|c|}
\hline \multirow{2}{*}{ Imię } & \multicolumn{2}{|c|}{$1848-1860$} & \multicolumn{2}{|c|}{$1861-1870$} & \multicolumn{2}{|c|}{$1871-1880$} & \multicolumn{2}{|c|}{$1881-1890$} & \multicolumn{2}{|c|}{$1891-1900$} & \multicolumn{3}{|c|}{$1848-1900$} \\
\hline & 1 & 2 & 1 & 2 & 1 & 2 & 1 & 2 & 1 & 2 & 2 & 1.b. & Sz.s \\
\hline 1 & 2 & 3 & 4 & 5 & 6 & 7 & 8 & 9 & 10 & 11 & 12 & 13 & 14 \\
\hline Marianna & 35 & 32,5 & 16,6 & 18,8 & 18,5 & 21,5 & 11,5 & 11,8 & 18,5 & 19,7 & 21,2 & 157 & 157 \\
\hline Aniela & & & 2,6 & 1,5 & 28,6 & 16,3 & 27,3 & 13,8 & 41,6 & 21,8 & 10,4 & 77 & 234 \\
\hline Katarzyna & 33,8 & 14,8 & 25,7 & 13,8 & 13,5 & 7,4 & 16,2 & 7,9 & 10,8 & 5,4 & 10 & 74 & 308 \\
\hline Helena & 8,5 & 3,6 & 39,4 & 20,3 & 25,4 & 13,3 & 12,7 & 5,9 & 14,1 & 6,8 & 9,6 & 71 & 379 \\
\hline Anna & 23,4 & 8,9 & 23,4 & 10,9 & 17,2 & 8,1 & 4,7 & 2 & 31,3 & 13,6 & 8,6 & 64 & 443 \\
\hline Karolina & 1,8 & 0,6 & & & 10,5 & 4,4 & 57,9 & 21,7 & 29,8 & 11,6 & 7,7 & 57 & 500 \\
\hline Zofia & 32,6 & 8,9 & 6,5 & 2,2 & 26,1 & 8,9 & 17,4 & 5,3 & 17,4 & 5,4 & 6,2 & 46 & 546 \\
\hline Tekla & 27,8 & 5,9 & 25 & 6,5 & 16,7 & 4,4 & 16,7 & 3,9 & 13,9 & 3,4 & 4,9 & 36 & 582 \\
\hline Salomea & 15,8 & 1,8 & 21,1 & 2,9 & 10,5 & 1,5 & 31,6 & 4 & 21,1 & 2,7 & 2,6 & 19 & 601 \\
\hline Apolonia & 53,3 & 4,7 & 26,7 & 2,9 & 6,7 & 0,7 & 13,3 & 1,3 & & & 2 & 15 & 616 \\
\hline Agnieszka & 18,2 & 1,2 & 45,5 & 3,6 & 18,2 & 1,5 & 18,2 & 1,3 & & & 1,5 & 11 & 627 \\
\hline Bronisława & 12,5 & 0,6 & & & 12,5 & 0,7 & & & 75 & 4,1 & 1,1 & 8 & 635 \\
\hline
\end{tabular}




\begin{tabular}{|c|c|c|c|c|c|c|c|c|c|c|c|c|c|}
\hline 1 & 2 & 3 & 4 & 5 & 6 & 7 & 8 & 9 & 10 & 11 & 12 & 13 & 14 \\
\hline Antonina & 42,9 & 1,8 & & & 28,6 & 1,5 & 14,3 & 0,7 & 14,3 & 0,7 & 1 & 7 & 642 \\
\hline Joanna & 33,3 & 1,2 & & & & & 50 & 2 & 16,7 & 0,7 & 0,8 & 6 & 648 \\
\hline Teresa & 66,7 & 2,4 & 33,3 & 1,4 & & & & & & & 0,8 & 6 & 654 \\
\hline Anastazja & 40 & 1,2 & 20 & 0,7 & & & 40 & 1,3 & & & 0,7 & 5 & 659 \\
\hline Balbina & 20 & 0,6 & & & 20 & 0,7 & 60 & 2 & & & 0,7 & 5 & 664 \\
\hline Józefa & 60 & 1,8 & & & 20 & 0,7 & 20 & 0,7 & & & 0,7 & 5 & 669 \\
\hline Justyna & 60 & 1,8 & & & & & 40 & 1,3 & & & 0,7 & 5 & 674 \\
\hline Rozalia & 60 & 1,8 & 40 & 1,4 & & & & & & & 0,7 & 5 & 679 \\
\hline Konstancja & & & & & 75 & 2,2 & 25 & 0,7 & & & 0,5 & 4 & 683 \\
\hline Ewa & 33,3 & 0,6 & & & & & 66,7 & 1,3 & & & 0,4 & 3 & 686 \\
\hline Klara & & & 33,3 & 0,7 & & & 33,3 & 0,7 & 33,3 & 0,7 & 0,4 & 3 & 689 \\
\hline Małgorzata & 33,3 & 0,6 & 33,3 & 0,7 & & & 33,3 & 0,7 & & & 0,4 & 3 & 692 \\
\hline Paulina & & & & & 33,3 & 0,7 & 63,7 & 1,3 & & & 0,4 & 3 & 695 \\
\hline Agata & & & 50 & 0,7 & 50 & 0,7 & & & & & 0,3 & 2 & 697 \\
\hline Albina & & & & & & & & & 100 & 1,4 & 0,3 & 2 & 699 \\
\hline Barbara & 50 & 0,6 & 50 & 0,7 & & & & & & & 0,3 & 2 & 701 \\
\hline Cecylia & & & 100 & 1,4 & & & & & & & 0,3 & 2 & 703 \\
\hline Domicella & & & 50 & 0,7 & & & 50 & 0,7 & & & 0,3 & 2 & 705 \\
\hline Dorota & & & & & 50 & 0,7 & 50 & 0,7 & & & 0,3 & 2 & 707 \\
\hline Eleonora & & & 100 & 1,4 & & & & & & & 0,3 & 2 & 709 \\
\hline Elżbieta & 50 & 0,6 & 50 & 0,7 & & & & & & & 0,3 & 2 & 711 \\
\hline Felicja & 50 & 0,6 & 50 & 0,7 & & & & & & & 0,3 & 2 & 713 \\
\hline Franciszka & & & 100 & 1,4 & & & & & & & 0,3 & 2 & 715 \\
\hline Krystyna & & & 50 & 0,7 & 50 & 0,7 & & & & & 0,3 & 2 & 717 \\
\hline Leona & & & & & & & 100 & 1,4 & & & 0,3 & 2 & 719 \\
\hline Ludwika & & & & & 50 & 0,7 & 50 & 0,7 & & & 0,3 & 2 & 721 \\
\hline Magdalena & 50 & 0,6 & & & & & 50 & 0,7 & & & 0,3 & 2 & 723 \\
\hline Wiktoria & & & 50 & 0,7 & & & & & 50 & 0,7 & 0,3 & 2 & 725 \\
\hline Bonifacja & 100 & 0,6 & & & & & & & & & 0,1 & 1 & 726 \\
\hline Emilia & & & & & & & 100 & 0,7 & & & 0,1 & 1 & 727 \\
\hline Gertruda & & & & & & & 100 & 0,7 & & & 0,1 & 1 & 728 \\
\hline Honorata & & & & & & & 100 & 0,7 & & & 0,1 & 1 & 729 \\
\hline Jadwiga & & & 100 & 0,7 & & & & & & & 0,1 & 1 & 730 \\
\hline Julianna & & & 100 & 0,7 & & & & & & & 0,1 & 1 & 731 \\
\hline Lucyna & & & 100 & 0,7 & & & & & & & 0,1 & 1 & 732 \\
\hline Maria & & & & & & & 100 & 0,7 & & & 0,1 & 1 & 733 \\
\hline Martyna & & & & & & & 100 & 0,7 & & & 0,1 & 1 & 734 \\
\hline Monika & & & & & 100 & 0,7 & & & & & 0,1 & 1 & 735 \\
\hline Petronella & & & & & & & 100 & 0,7 & & & 0,1 & 1 & 736 \\
\hline Regina & & & & & 100 & 0,7 & & & & & 0,1 & 1 & 737 \\
\hline Róża & & & & & 100 & 0,7 & & & & & 0,1 & 1 & 738 \\
\hline Teofila & & & & & & & 100 & 0,7 & & & 0,1 & 1 & 739 \\
\hline Waleria & & & & & & & & & 100 & 0,7 & 0,1 & 1 & 740 \\
\hline Weronika & & & & & & & & & 100 & 0,7 & 0,1 & 1 & 741 \\
\hline
\end{tabular}

Źródło: AP, Księga urodzeń (ochrzczonych) 1841-1889, 1890-1906. 1 - \% imienia w danym okresie do ogólnej liczby tego imienia; 2 - \% imienia do ogólnej liczby imion w danym przedziale czasowym. 
Żeńskie imiona pogrupowano podobnie jak to miało miejsce w przypadku imion nadanym chłopcom ${ }^{24}$. W grupie najczęściej nadawanych (od $3 \% \mathrm{w}$ górę) odnotowano osiem. W sumie stanowiły one ponad $78 \%$ wszystkich imion nadanym dziewczynkom w latach 1848-1900. Był to wyższy odsetek niż dla imion męskich zaliczonych do tej samej kategorii (prawie o 8\%); znacznie niższy natomiast był w grupie średnio popularnych (wyodrębniono ich cztery, a procentowy udział to $7,2 \%$ gdy dla chłopców wyniósł $20 \%$ ). Dużo większe zróżnicowanie stwierdzono natomiast dla imion, które uznano za sporadyczne. Wyodrębniono tu 44 rodzaje, a dzieci nimi ochrzczone stanowiły ponad $14,3 \%$. W tej grupie czternastu użyto tylko raz.

Rozbijając cały badany okres na pięć przedziałów czasowych możemy prześledzić, podobnie jak to miało miejsce w chrztach chłopców, spore wahania w repertuarze wybieranych imion. W latach $1848-1860$ było ich 26 . W następnej dekadzie liczba ta wzrosła do 28 , a progres ten był związany z pojawieniem się 12 nowych imion. Dalszy spadek chrztów miał miejsce w następnym dziesięcioleciu i był on połączony z równoczesnym obniżeniem się ich różnorodności (24); zanotowano także siedem imion, które nie wystąpiły we wcześniejszych latach. Znaczny wzrost miał natomiast miejsce w latach osiemdziesiątych XIX wieku. Tutaj repertuar wybieranych imion był najszerszy z całego badanego okresu. Odnotowano ich 34 (w tym osiem nowych nie występujących wcześniej), co w stosunku do poprzedniego dziesięciolecia stanowiło wzrost o prawie $30 \%$. Uwagę zwraca tu fakt, że w tej samej dekadzie różnorodność w wyborze imienia dla chłopców była także największa. Ostatnie lata XIX wieku to zdecydowane obniżenie się rodzajów nadanych imion - do 17. Wystąpiły również 3 nowe, co także było sporym regresem w stosunku do wcześniejszych lat.

Podobnie jak w przypadku chrztów chłopców, tak i dla dziewczynek, wzrost liczby nadawanych imion związany był z obniżeniem się odsetka wśród imion najpopularniejszych. Najwyższą wartość osiągnął on w latach 1871-1880 $84,4 \%$. Wtedy też odnotowano najmniej zróżnicowane imiennictwo (24 imiona). Najniższy odsetek w obrębie tej grupy przypadł na lata osiemdziesiąte $(72,4 \%)$. Tak znaczny spadek odbił się na liczebności imion, na których wybór decydowano się sporadycznie. Osiągnęły one wówczas swoje maksimum $(21,1 \%$ wszystkich imion w tym dziesięcioleciu). Największe nasilenie chrztów, w których dziecko otrzymało imię $\mathrm{z}$ grupy średnio popularnych miało miejsce w latach 1861-1870 $(9,4 \%)$. Minimum dla tej kategorii odnotowano dla następnego dziesięciolecia $(4,4 \%)$. Porównując procentowe udziały w trzech wyodrębnionych przez nas grupach imion dla noworodków płci męskiej i żeńskiej widać, że dziewczynkom częściej nadawano imiona z grupy pierwszej niż z drugiej. Większy odsetek stanowiły natomiast imiona, których udział w ogólnej ich liczbie wyniósł poniżej 1\%.

Najczęściej nadawanych na chrzcie imieniem żeńskim była Marianna ${ }^{25}$ (ponad $21 \%$ ). Był to wyższy odsetek aniżeli w przypadku Jana. Dalej znalazły się:

\footnotetext{
${ }^{24} \mathrm{~W}$ wypadku gdy dziecko miało dwa imiona, pod uwagę brano tylko pierwsze.

${ }^{25}$ Marianna jest jedną z form imienia Maria. W naszym źródle stwierdzono jeden zapis Marii, pod rokiem 1887. Por. A. Tomecka, Imiona chrzestne, s. 162-164; S. Dziadkowiec, Imiona mieszkańców wsi, s. 80-84. Imię to „w dawnej Polsce nie było używane ze względu na fakt szczególnej
} 
Aniela - 10,4 \%, Katarzyna - 10\%. Z pozostałych pięciu imion, które przekroczyły próg 3\%, jako ostatnią odnotowano Teklę - 4,9\%. Śledząc zmiany jakie zachodziły w wyborze tych imion na przestrzeni czasu, na komentarz zasługuje wysoki odsetek Marianny w latach 1848-1860 (35\% $)^{26}$. W latach następnych procent ten spada, by osiągnąć najmniejszą wartość w latach osiemdziesiątych. Równocześnie ze spadkiem tym był powiązany malejący udział tego imienia w stosunku do ogółu. Inna tendencja wystąpiła przy imieniu Aniela. Do 1860 roku nie stwierdzono ani jednego chrztu, na którym nadano by to imię. Począwszy od następnej dekady miał miejsce stały wzrost, który osiągnął swoje maksimum w ostatnim dziesięcioleciu XIX wieku (41,6\%). Charakterystyczne jest to, że moda na imię Aniela rozpowszechniła się, w skali całego kraju, w wieku XIX. Dużą popularnością imię to cieszyło się zwłaszcza wśród rzemieślników i chłopów ${ }^{27}$. W konsekwencji, procentowy udział $\mathrm{w}$ gronie wszystkich imion żeńskich w tym przedziale czasowym był najwyższy i wyniósł prawie $22 \%$.

$\mathrm{Z}$ ośmiu imion zaliczonych do najczęstszych, wyróżnia się także Karolina. W pierwszym okresie odsetek był znikomy, w drugim dziesięcioleciu nie ochrzczono ani jednej dziewczynki tym imieniem, natomiast w latach 1881-1890 nastąpił znaczny progres (prawie $60 \%$ ). Miało to też swoje odzwierciedlenie w stosunku do pozostałych imion (21,7 \% ogółu).

Do imion z grupy od 1\% do 3\% zaliczono tylko cztery: Salomeę, Apolonię, Agnieszkę i Bronisławę. Było to znacznie mniej aniżeli w przypadku chłopców, gdzie imion z tej grupy było dwanaście. Spośród tej czwórki, najbardziej charakterystyczny rozkład miał miejsce w przypadku Bronisławy. W dwóch dekadach nie wystąpiło ono ani razu (w 1861-1870 i 1881-1890), za to w latach dziewięćdziesiątych stanowiło $75 \%$ wszystkich noworodków płci żeńskiej ochrzczonych tym imieniem. Nie nadawano natomiast $w$ ostatnim dziesięcioleciu XIX wieku imion Apolonia i Agnieszka.

czci, jaką otaczano osobę Matki Bożej [...], używano form pochodzących od tego imienia, takich jak np. Marianna, Maryna”. H. Fros, F. Sowa, Twoje imię. Przewodnik onomastyczno-hagiograficzny, Kraków 1975, s.399; „W ciągu XIX wieku w miarę rozpowszechnienia się Marii, Marianna staje się coraz rzadsza, utrzymuje się ona dłużej we wsiach, zwłaszcza tam gdzie księża starym zwyczajem niechętnie patrzyli na używanie imienia Maria. Bystroń, Księga imion w Polsce, s. 270;

${ }^{26}$ Zob. Sułowski, Imiona chrzestne w parafii, s 105.

${ }^{27} \mathrm{~W}$ tabeli 4 wspomnienie św. Anieli odnotowano (za kalendarzem Jaworskiego) 4.I. Rosnąca, począwszy od lat 70 XIX w., liczba chrztów, na których nadawano to imię, była spowodowana zapewne kultem innej świętej. Chodzi tu św. Anielę Merici, urodzoną ok. 1470 we Włoszech, założycielkę Zgromadzenia Sióstr Urszulanek. Aniela Merici została beatyfikowana w roku 1768, a kanonizowana 24 maja 1807 roku (wspomnienie przypada 27 I). Na ziemie polskie urszulanki przybyły w 1857 roku. Otworzyły szkołę z internatem w Poznaniu, a następnie w Gnieźnie. Po kilkunastu latach Kulturkampfu zmuszone zostały do przesiedlenia się z Poznania do Krakowa i z Gniezna do Tarnowa. Rozpoczęły także posługę we Lwowie. Oprócz działalności urszulanek, do rozpowszechnienia kultu Anieli przyczynili się, zapewne, w swoich utworach poeci: T. Lenartowicz i K. Koźmian. Warto także pamiętać, że na popularność imienia Aniela (łac. Angela) mógł mieć wpływ szeroko rozpowszechniony kult aniołów, zwłaszcza kult aniołów stróżów (Angeli custodes). H. Fros, F. Sowa, Księga imion, t. 1, Kraków 1997, s. 179. B. Kupis, Najciekawsze imiona, Warszawa 1999, s. 49-51. B. Kumor, Historia Kościoła, cz. 7: Czasy najnowsze 1815-1914, Lublin 1991, s. 401-405. 
W Iskrzyni w latach 1848-1900 piętnaście dziewczynek otrzymało na chrzcie podwójne imiona ${ }^{28}$, co stanowiło $2 \%$ wszystkich imion żeńskich. W porównaniu z noworodkami płci męskiej odsetek ten był dwukrotnie niższy. Podobny był natomiast rozkład chrztów w czasie. Ponad $73 \%$ miało miejsce po roku 1875 , a na nadanie imienia podwójnego najczęściej decydowano się w latach osiemdziesiątych $(47 \%)$.

Tabela 4. Sezonowość nadawania imion żeńskich

\begin{tabular}{|c|c|c|c|c|c|c|c|c|c|c|c|c|c|c|c|}
\hline \multirow[b]{2}{*}{ Imię i data święta* } & \multicolumn{12}{|c|}{ Miesiące } & \multirow[b]{2}{*}{ 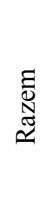 } & \multirow[b]{2}{*}{ 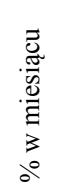 } & \multirow[b]{2}{*}{$\begin{array}{l}\frac{0}{\pi} \\
\frac{\sqrt[T]{\pi}}{3} \\
\frac{3}{3} \\
\frac{3}{3} \\
0\end{array}$} \\
\hline & 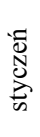 & 导 & 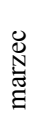 & 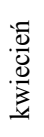 & '尹্ট̆ & 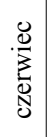 & $\stackrel{\mathscr{E}}{\stackrel{\Xi}{G}}$ & $\frac{\frac{0}{2}}{\frac{0}{2}}$ & $\begin{array}{l}\cdot \frac{\sqrt{N}}{\mathrm{~N}} \\
\frac{N}{3}\end{array}$ & 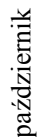 & 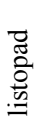 & 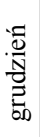 & & & \\
\hline 1 & 2 & 3 & 4 & 5 & 6 & 7 & 8 & 9 & 10 & 11 & 12 & 13 & 14 & 15 & 16 \\
\hline Aniela 4 I & 8 & 12 & 8 & 6 & 7 & 5 & 8 & 4 & 5 & 9 & 4 & 1 & 77 & 10,4 & 27,3 \\
\hline Katarzyna $30 \mathrm{IV}, 25 \mathrm{XI}$ & & 6 & 7 & 10 & 2 & 4 & 3 & 5 & 5 & 12 & 15 & 5 & 74 & 33,8 & 68,9 \\
\hline Helena 2 III, $21 \mathrm{~V}$ & 4 & 9 & 9 & 8 & 5 & 9 & 2 & 8 & 3 & 5 & 4 & 3 & 71 & 19,7 & 56,3 \\
\hline Anna 26 VII & 8 & 2 & 5 & 7 & 4 & 11 & 14 & 6 & 2 & 4 & & 1 & 64 & 21,9 & 40,6 \\
\hline Karolina 5 VII & 6 & 8 & 5 & 9 & 7 & 3 & 3 & 2 & 3 & 3 & 7 & 1 & 57 & 5,3 & 14 \\
\hline Zofia $15 \mathrm{~V}$ & 2 & 1 & 5 & 10 & 20 & 2 & 1 & & 2 & 1 & 1 & 1 & 46 & 43,5 & 69,6 \\
\hline Tekla 25 IX & 1 & 4 & 4 & 3 & 2 & 1 & & 5 & 8 & 3 & 1 & 4 & 36 & 22,2 & 44,4 \\
\hline Salomea 17 XI & 1 & 1 & 1 & 1 & 1 & 1 & 1 & 1 & & 2 & 7 & 2 & 19 & 36,8 & 57,9 \\
\hline Apolonia 9 II & 6 & 2 & & & & 1 & & 1 & 1 & 1 & & 3 & 15 & 13,3 & 53,3 \\
\hline Agnieszka $21 \mathrm{I}$ & 6 & 1 & & 1 & & 1 & & & & 1 & & 1 & 11 & 54,6 & 72,7 \\
\hline Bronisława 1 IX & 1 & & 1 & & & 3 & 1 & 2 & & & & & 8 & & 25 \\
\hline Antonina 16 XII & 1 & & 1 & 1 & 1 & 1 & 1 & & 1 & & & & 7 & & 14,3 \\
\hline Joanna $24 \mathrm{~V}$ & & 1 & & & 1 & & 1 & 1 & 1 & 1 & & & 6 & 16,7 & 16,7 \\
\hline Teresa $15 \mathrm{X}$ & & & & 1 & & & & & & 5 & & & 6 & 83,3 & 83,3 \\
\hline Anastazja 15 IV & & & & 2 & & 1 & & & & & & 2 & 5 & 40 & 40 \\
\hline Balbina 31 III & & 1 & 1 & 1 & & 1 & & & & & 1 & & 5 & 20 & 60 \\
\hline Józefa 14 II & & 1 & 2 & & 1 & & & & & & 1 & & 5 & 20 & 60 \\
\hline Justyna $7 \mathrm{X}$ & & 1 & & & & & & 1 & 1 & 2 & & & 5 & 40 & 60 \\
\hline Rozalia 2 IX & & & 1 & 2 & & & & 1 & 1 & & & & 5 & 20 & 40 \\
\hline Konstancja 18 II & & 3 & 1 & & & & & & & & & & 4 & 75 & 100 \\
\hline Ewa 24 XII & & & & 1 & 1 & & & & 1 & & & & 3 & & \\
\hline Klara 12 VIII & & & & & & & & 3 & & & & & 3 & 100 & 100 \\
\hline Małgorzata $13,20 \mathrm{VII}$ & & & & & & 1 & 2 & & & & & & 3 & 66,7 & 100 \\
\hline Paulina 26 I & 1 & & & 1 & & 1 & & & & & & & 3 & 33,3 & 33,3 \\
\hline Agata 5 II & & 2 & & & & & & & & & & & 2 & 100 & 100 \\
\hline Albina $16 \mathrm{XII}$ & & & 2 & & & & & & & & & & 2 & & \\
\hline Barbara 4 XII & & & & & & & & & & & 1 & 1 & 2 & 50 & 100 \\
\hline Cecylia 22 XI & & & & & & & & & & & 2 & & 2 & 100 & 100 \\
\hline Domicella $7 \mathrm{~V}$ & & & & & 1 & & & & 1 & & & & 2 & 50 & 50 \\
\hline
\end{tabular}

${ }^{28}$ „,[...]. Z tym ostatnim okresem należy też związać zwyczaj dwuimienności. I tak na przykład w Sadach, do końca XVIII wieku mamy 5\% dziewcząt dwuimiennych, gdy tymczasem w XIX w. liczba ta wynosi 18\%", Sułowski, Imiona chrzestne w Polsce, s. 96. 


\begin{tabular}{|c|c|c|c|c|c|c|c|c|c|c|c|c|c|c|c|}
\hline 1 & 2 & 3 & 4 & 5 & 6 & 7 & 8 & 9 & 10 & 11 & 12 & 13 & 14 & 15 & 16 \\
\hline Dorota 6 II & & 1 & & & & & & 1 & & & & & 2 & 50 & 50 \\
\hline Eleonora $21 \mathrm{II}$ & & 2 & & & & & & & & & & & 2 & 100 & 100 \\
\hline Elżbieta 5 XI & & & & & 1 & & & & & 1 & & & 2 & & 50 \\
\hline Felicja 24 I & 1 & & & & & & & & & & 1 & & 2 & 100 & 50 \\
\hline Franciszka 9 III & & & 2 & & & & & & & & & & 2 & 100 & 100 \\
\hline Krystyna 24 VII & & 1 & & & & & & 1 & & & & & 2 & & 50 \\
\hline Leona 15 VI & & & & 1 & & & & & & 1 & & & 2 & & \\
\hline Ludwika 15 IV & & & 1 & & & & & 1 & & & & & 2 & & 50 \\
\hline Magdalena $25 \mathrm{~V}, 22 \mathrm{VII}$ & 1 & & & & & & 1 & & & & & & 2 & 50 & 50 \\
\hline Wiktoria 23 XII & & & & & & & & & & & & 2 & 2 & 100 & 100 \\
\hline Bonifacja 5 VI & & & & 1 & & & & & & & & & 1 & & \\
\hline Emilia $30 \mathrm{VI}$ & & & & & & 1 & & & & & & & 1 & 100 & 100 \\
\hline Gertruda 16 XI & & & & & & & & & & & 1 & & 1 & 100 & 100 \\
\hline Honorata 12 I & 1 & & & & & & & & & & & & 1 & 100 & 100 \\
\hline Jadwiga $15 \mathrm{X}$ & 1 & & & & & & & & & & & & 1 & & \\
\hline Julianna 16 II & & & & & & 1 & & & & & & & 1 & & \\
\hline Lucyna $30 \mathrm{VI}$ & & & & & & & 1 & & & & & & 1 & & 100 \\
\hline Martyna 30 I & 1 & & & & & & & & & & & & 1 & 100 & 100 \\
\hline Monika 4 V & & & & & 1 & & & & & & & & 1 & 100 & 100 \\
\hline Petronella $31 \mathrm{~V}$ & & & & & & & & & & & 1 & & 1 & & \\
\hline Regina 7 IX & & & & & & & & & 1 & & & & 1 & 100 & 100 \\
\hline Róża 26 VIII & & & & & & & & 1 & & & & & 1 & 100 & 100 \\
\hline Teofila 28 XII & & & & & 1 & & & & & & & & 1 & & \\
\hline Waleria 5 VI & & & 1 & & & & & & & & & & 1 & & \\
\hline Weronika 13 I & & & & & & & & & & & 1 & & 1 & & \\
\hline Razem & 50 & 59 & 57 & 66 & 57 & 48 & 39 & 44 & 36 & 51 & 48 & 29 & 584 & $\mathrm{x}$ & $\mathrm{x}$ \\
\hline $\begin{array}{l}\text { W tym w miesiącu } \\
\text { święta }\end{array}$ & 18 & 11 & 12 & 12 & 28 & 1 & 20 & 4 & 10 & 7 & 25 & 3 & $\mathrm{x}$ & 151 & 282 \\
\hline $\begin{array}{c}\text { \% w miesiącu } \\
\text { święta }\end{array}$ & ల & $\begin{array}{l}0 \\
\infty \\
-1\end{array}$ & $\vec{\approx}$ & $\stackrel{\sim}{\infty}$ & $\vec{a}$ & $\vec{i}$ & $\frac{\pi}{n}$ & $\vec{a}$ & $\stackrel{\infty}{\sim}$ & $\hat{n}$ & in & $\stackrel{n}{0}$ & $\mathrm{x}$ & 25,9 & 48,3 \\
\hline
\end{tabular}

Sezonowość nadawania imion żeńskich różniła się od sezonowości imion męskich (tabela 4). Odsetek chrztów imieniem patronki, której święto przypadało w tym samym miesiącu był prawie dwukrotnie niższy niż u chłopców (25,9\%); na taki stan największy wpływ miały tu miesiące: czerwiec, sierpień oraz grudzień, w których nie było żadnego takiego święta. Właściwym miernikiem w takiej sytuacji wydaje się odsetek chrztów w kwartale święta; przypadało ich 48,3\% - czyli prawie tyle, ile męskich w miesiącu święta $(47,4 \%)$.

W naszej statystyce nie uwzględniono najpopularniejszego imienia - Marianny. Co piąta ochrzczona dziewczynka otrzymała to imię. Było ono nadawane regularnie przez cały rok. Z imieniem tym związany był bowiem kult wyrażający się poprzez częste obchodzenie świąt maryjnych ${ }^{29}$. I tak, na przestrzeni roku: 2

\footnotetext{
${ }^{29}$ Wielką frekwencją w całej okolicy cieszył się odpust Pocieszenia N.M.P. w Komborni, który
} 
lutego - uroczyście świętowano Matki Boskiej Gromnicznej, 25 marca - Zwiastowanie, 15 sierpnia - Wniebowzięcie, 8 grudnia - Niepokalane Poczęcie. Stosunkowo równy rozkład częstości występowania tego imienia w poszczególnych miesiącach, powiązany z dużą liczbą świąt, uniemożliwia stwierdzenie zależności pomiędzy datą święta, a wyborem imienia ${ }^{30}$.

Z najczęściej wybieranych imion, najwyższy odsetek chrztów danym imieniem w miesiącu święta osiągnęła Katarzyna (33,8\%). W tym przypadku bardziej rozpowszechnione było święto Katarzyny aleksandryjskiej (25 XI) niż Katarzyny sieneńskiej (30 IV). Listopadowe święto tej patronki spowodowało, że miesiąc ten miał najwyższy odsetek zgodności chrztów ze świętem patrona $\mathrm{w}$ roku $(52,1 \%)$. Jeszcze większą zgodność odnotowano dla Zofii, którą wspominano 15 $\mathrm{V}(43,5 \%)$. Gdyby rozszerzyć tę zależność na miesiąc przed i miesiąc po święcie, to otrzymalibyśmy prawie $70 \%$ chrztów w obrębie tego imienia. Majowe święto Zofii, z tak wysokim odsetkiem ochrzczonych w tym miesiącu, zadecydowało o wysokim współczynniku miesięcznym (49,1\%). Wśród imion, które znalazły się w grupie $1 \%-3 \%$ (tab. 4), wysoki procent chrztów danym imieniem w miesiącu święta osiągnęła Agnieszka $(54,6 \%)$; w kwartale było to prawie $73 \%$. Z imion rzadziej używanych, mających zazwyczaj wyższe odsetki, zwraca uwagę grupa dziesięciu, które nie wystąpiły w ogóle w kwartale święta. Spośród piętnastu imion zanotowanych tylko jeden raz, aż osiem nie wystąpiło w miesiącu wspomnienia patrona.

\section{Wnioski}

Reasumując, możemy stwierdzić, że mieszkańcy Iskrzyni decydując się na imię chrzestne dla swoich dzieci wybierali tylko takie, które występowały w kalendarzu liturgicznym. Były to imiona biblijne, starochrześcijańskie lub świętych średniowiecza. Wśród tych ostatnich znalazło się też kilka imion słowiańskich noszonych przez świętych z Polski, Węgier i Czech (np. Czesław, Kazimierz, Stanisław, Wojciech) ${ }^{31}$.

Repertuar imion był szeroki. W całym przebadanym okresie (1848-1900) nadano 59 imion męskich, a do najpopularniejszych należały: Jan, Stanisław, Józef, Paweł, Wojciech, Michał, Jakub, Antoni. Spośród 56 imion żeńskich najczęściej wybierano: Mariannę, Anielę, Katarzynę, Helenę, Annę, Karolinę, Zofię i Teklę.

wypadał w niedzielę po uroczystości św. Augustyna, czyli w ostatnich dniach sierpnia albo w pierwszych września. M. Pelczar, A. Lorens, Sześćset lat doli i niedoli Krościenka Wyżnego i Iskrzyni 1350-1950, Krościenko Wyżne 1997, s. 189.

${ }^{30}$ Więcej na temat kultu maryjnego zob. Cz. Deptuła, $Z$ zagadnień historii kultu maryjnego w Polsce, „Ateneum Kapłańskie”, 52 (1960) t. 60, z. 3, s. 392-419; A. Witkowska, Ośrodki kultu maryjnego na ziemiach polskich w XIX wieku, w: Niepokalana. Kult Matki Bożej na ziemiach polskich w XIX wieku, red. B. Pylak, Cz. Krakowiak, Lublin 1988, s. 90-91; J. J. Kopeć, Formy kultu maryjnego w polskiej religijności XIX wieku, „Roczniki Teologiczne”, 43 (1996) z. 4, s. 165-187.

${ }^{31}$ Zob. Malec, Imię w polskiej antroponimii, s. 17-33. 
Wpływ kalendarza kościelnego na wybór imienia podkreślają wyniki analizy frekwencyjności. Decydują rolę odgrywał czas narodzin. Dziecko otrzymywało na chrzcie imię tego patrona, którego wspomnienie przypadało na dzień narodzin - chrztu ${ }^{32}$ lub na okres sąsiadujący z tym świętem. Wydaje się, że zależność ta jest bardziej widoczna w przypadku imion męskich niż żeńskich. Wśród tych drugich, $\mathrm{z}$ imion zaliczonych pod względem częstości występowania do grupy $1 \%-3 \%$, tylko Bronisława nie przekroczyła 50\% chrztów w kwartale. Z imion najpopularniejszych, pięć z siedmiu osiągnęło próg 40\% (w kwartale święta). Dla chłopców odsetek był znacznie wyższy (tylko dwa imiona z grona dziewięciu miało poniżej $60 \%$ ). Najczęściej wybierane imię Marianna (ponad $21 \%$ nominacji), nadawano przez cały rok, co wynikało z dużej liczby świąt maryjnych. Fakt ten rzutował $\mathrm{z}$ kolei na całą frekwencję $e^{33}$.

Jednym z czynników mających wpływ na wybór imienia chrzestnego było także oddziaływanie duchowieństwa. Do najpopularniejszych należały imiona aktualnie urzędujących proboszczów (Andrzej, Roman, Wincenty).

Analizując motywy wyboru imienia warto pamiętać, że odkrycie prawdziwych motywacji jest bardzo trudne. W pewnym stopniu dyskusyjna jest metoda zliczania imion w miesiącu poprzedzającym i następującym po święcie danego patrona. Dużo wątpliwości pojawia się także, gdy nominację uzasadniamy dziedziczeniem po rodzicach. Jeśli imię jest tożsame np. z imieniem lokalnie czczonego świętego, patronem kościoła i okresowo panującą modą, trudno wówczas wyrokować o motywach takiego wyboru.

${ }^{32}$ Więcej na temat liczby dni między urodzeniem i chrztem zob. P. Rachwał, Ludność wsi Iskrzynia w powiecie krośnieńskim w XIX w., PDP, 27 (2006), s. 77-79.

${ }^{33}$ Por. $\mathrm{z}$ frekwencyjnością nadawania imienia Jan. 


\title{
THE CHRISTIAN NAMES OF ISKRZYNIA INHABITANTS IN THE 19TH CENTURY. BASED ON THE REGISTERS OF THE KROŚCIENKO WYŻNE PARISH FROM THE YEARS 1848-1900
}

\begin{abstract}
Summary
The basic sources for research on the names of Iskrzynia inhabitants in the 19th century were baptismal registers from the years 1848-1900. The author focused on different factors which could affect the choice of a Christian name, that is to say, family tradition, literary influence, changing fashion. It was also pointed out that the relation between the date of baptism and a saint patron played an important role in deciding on a name for a child.

Over $47 \%$ of boys received the names of patrons whose days were in the month of their baptism, for girls the percentage was almost $26 \%$.

The range of Iskrzynia inhabitants' names given in baptism is wide. In the studied period there were 59 kinds of male names and 59 female ones. The most popular male names were: Jan, Stanisław, Franciszek, Józef and female ones: Marianna, Aniela, Katarzyna and Helena.
\end{abstract}

